\title{
Pengukuran Usability Pada E-Learning Politeknik Negeri Jakarta
}

\author{
Rachmah Nanda Kartika ${ }^{1}$, Emmidia Djonaedi ${ }^{2)}$ \\ ${ }^{1,2)}$ Teknik Grafika dan Penerbitan, Politeknik Negeri Jakarta, \\ Jl.Prof. Siwabessy, Kampus baru UI Depok 1624 \\ E-mail: rachmah.nandakartika@grafika.pnj.ac.id, E-mail : emmidia.djonaedi@grafika.pnj.ac.id
}

\begin{abstract}
Abstrak - Covid-19 berdampak besar pada kegiatan dunia termasuk pendidikan. Kegiatan belajar mengajar yang semula bertatap muka berubah menjadi kegiatan belajar mengajar dari jarak jauh atau kuliah daring. Untuk mendukung upaya pemerintah dalam pencegahan penyebaran virus Covid-19 tersebut, Politeknik Negeri Jakarta juga melaksanakan perkuliahannya secara daring dengan menggunakan media E-learning PNJ. Sebuah sistem media pembelajaran dikatakan baik apabila kebutuhan pengguna dapat terpenuhi seperti kemudahan penggunaan tools pada E-learning. E-learning harus memenuhi pencapaian kompetensi baik matakuliah teori maupun praktek. Program studi yang menjadi target penelitian adalah teknik grafika, teknologi industri cetak kemasan, teknik mesin, kontruksi gedung, dan konversi energi. Namun saat ini, pencapaian kompetensi pembelajaran praktek tersebut belum bisa terpenuhi seperti pada saat proses perkuliahan luring. Agar proses kegiatan belajar mengajar jarakjauh menggunakan E-learning PNJ dapat berjalan efektif. Maka diperlukannya pengukuran usability pada E-learning PNJ. Pengukuran usability pada penelitian ini menggunakan tool kuesioner USE. Hasil pada penelitian ini diperoleh hasil dari 150 responden ialah tingkat usability pada e-learning PNJ sebesar 0,609. Angka tersebut termasuk kedalam kategori level usability baik. Namun, nilai tersebut masih berada dalam kriteria nilai minimun untuk kategori baik Adapun nilai untuk setiap varibelnya yaitu variabel uselfulness sebesar 71,4\%, variabel easy of use sebesar 72,8\%, variabel easy of learning sebesar 48,25 $\%$ dan kepuasan sebesar 51,2\% akan proses pembelajan jarak jauh teori dan praktek menggunakan E-learning, Adapun system e-learning yang diperbaiki yakni pada bigbluebutton, attendance, login, serta tambahan fitur notifikasi untuk tugas dan attendance mahasiswa.
\end{abstract}

Kata kunci: Covid 19, E-learning, usability, USE, Skala Likert.

\begin{abstract}
Covid-19 has impacted human activities around the world, including education. Teaching and learning activities that were originally conducted face-to-face have turned into remote teaching and learning activities or online lectures. To support the government's efforts to prevent Covid-19 from spreading further, the Jakarta State Polytechnic conducts its lectures using PNJ's E-learning media. Learning media systems can be considered reliable if they can fulfill user needs, such as the ease of using tools in E-learning. E-learning must be able to be used in both theoretical and practical subjects. The research targets for this study are graphic engineering, packaging printing industry technology, mechanical engineering, building construction, and energy conversion. However, these practical learning competencies cannot be achieved as conducted on the offline lecture. To ensure that the teaching and learning activities using PNJ E-learning can run effectively, we need to measure its usability. In this study, we use USE questionnaire tool as usability measurement. The research conducted on 150 respondents showed that the level of usability in PNJ e-learning was 0,609 this figure is included in the category of good usability level. However, this value is still within the minimun score criteria for the good category. The Value for each variable, namely the uselfulness variable of $71.4 \%$, the easy of use variable of $72.8 \%$, the easy of learning variable of $48.25 \%$ and the satisfaction of $51.2 \%$ of the long distance learning process. theory and practice using E-learning,. E-learning system's components that are improved are the bigbluebutton, attendance, login, additional notification features for student assignments, and attendance.
\end{abstract}

Keyword: E-learning, usability, USE, Likert. 


\section{PENDAHULUAN}

Virus Covid 19 pertama kali muncul di China pada bulan November 2019, hingga November 2020 menjangkit sebanyak total 60.264.241 jiwa di dunia dengan jumlah penderita covid di Indonesia sebanyak 516.753 jiwa [1]. Kondisi tersebut membuat pemerintah Indonesia melakukan Tindakan preventif untuk menekan penyebaran COVID-19 dengan melakukan program Pembatasan Sosial Berskala Besar (PSBB) dengan menghimbau masyarakat untuk bekerja, belajar, dan beribadah dari rumah [2]. Program tersebut berdampak besar pada banyak sektor, tak terkecuali pada dunia Pendidikan. Kegiatan belajar mengajar tatap muka beralih menjadi kegiatan dari jarak jauh atau melalui proses daring.

Politeknik Negeri Jakarta (PNJ) adalah salah satu institusi Pendidikan yang mendukung program perkuliahan secara online dengan menggunakan media e-learning. Program studi Teknik Grafika PNJ merupakah salah satu contoh prodi yang mengalihkan $100 \%$ kegiatan belajar mengajar teoritis dan praktik secara daring menggunakan e-learning. Perubahan sistem belajar mengajar tersebut harus didukung dengan sistem e-learning yang baik agar capaian pembelajaran dapat terpenuhi. Adapun penelitian terdahulu terkait usability e-learning dengan metode uselearn di salah satu perguruan tinggi di Bandung menghasilkan 10 kriteria dimensi baru dengan melakukan evaluasi indeks usabilitinya [3]. Penelitian lainya oleh [4] mengevaluasi usability pada web based learning SMK Gama Cendekia Surabaya menggunakan evaluasi heuristic menghasilkan nilai peningkatan efektivitas usability sebesar 10\%. Namun, hingga saat ini belum ada penelitian yang mengevaluasi usabilitas e-learning PNJ. Terlebih lagi dengan adanya perubahan significant pada proses belajar mengajar menjadi daring, penelitian pengukuran usability pada e-learning PNJ memiliki urgensi yang tinggi untuk dilakukan.

\section{LANDASAN TEORI}

\subsection{Usability}

Usability adalah bagian dari ilmu Ergonomi yang menilai sejauh mana produk dapat digunakan dengan mudah melalui kriteria tertentu. pengukuran usability digunakan untuk mengukur kemudahan dipelajari, efektifitas serta berinteraksi tanpa kesulitan atau kesalahan. Adapun kriteria yang dimaksud antara lain dapat dipelajari dengan mudah, memberi kepuasan penggunaan, mudah digunakan, efektif, efesien dan dapat diakses dengan mudah [5]. Penjelasan mengenai masing-masing kriteria tersebut ialah sebagai berikut :

\section{1) Uselfulness}

Sejauh mana pengguna dapat menggunakan suatu produk untuk mencapai tujuannya.

2) Efficiency

Merupakan waktu yang di perlukan oleh pengguna untuk mencapai tujuannya dalam menggunakan suatu produk.

3) Effectiveness

Merupakan kemudahan pengguna menggunakan suatu produk dengan apa yang di inginkan.

4). Learnability .

$$
\text { Kemampuan pengguna dalam }
$$
mengoperasikan sebuah system dan merupakan bagian dari effectiveness.

5) Satisfaction

Mengacu pada opini pengguna, perasaan, serta persepsi terhadap penggunaan suatu produk.

6) Accessibility

Dalam mencapai tujuan penggunaan, accessibility merupakan kemudahan akses dalam prosesnya.

Ada beberapa level usability [6]. Penilaiannya dapat dilihat pada tabel

Tabel 2.1 Level Usability

\begin{tabular}{llllll}
\hline $\begin{array}{l}\text { Poin, } \\
\mathrm{x}\end{array}$ & $0 \leq \mathrm{x} \leq 0.2$ & $0,2<\mathrm{x}$ & $0,4<\mathrm{x}$ & $0.6<\mathrm{x}$ & $0.8<\mathrm{x}$ \\
& & $\leq 0,4$ & $\leq 0,6$ & $\leq 0,8$ & $\leq 1.0$ \\
& & & & \\
\hline $\begin{array}{l}\text { Level } \\
\text { Usability }\end{array}$ & Jelek & Buruk & Sedang & Baik & $\begin{array}{l}\text { Sangat } \\
\text { Baik }\end{array}$
\end{tabular}

Keterangan :

- Jika nilai poin $\mathrm{x} \geq 0$, dan $\mathrm{x} \leq 0,2$ maka usability pada level Jelek

- Jika nilai poin $\mathrm{x} \geq 0,2$ dan $\mathrm{x} \leq 0,4$ maka usability pada lebel buruk

- Jika nilai poin $\mathrm{x}>0,4$ dan $\leq 0,6$ maka usability pada level sedang

- Jika nilai poin $\mathrm{x}>0,6$ dan $\mathrm{x} \leq 0,8$ maka usability pada level baik

- Jika nilai poin $\mathrm{x}>0,8$ dan $\mathrm{x} \leq 1$ maka usability pada level sangat baik

\subsection{USE Questionnaire}

USE Questionnaire merupakan alat untuk menilai usability melalui penilaian kepuasan pengguna 
melalui factor kebergunaan (uselfulness), kemudahan dalam penggunaan (ease of use) dan kepuasan (satisfaction) [7].

\subsection{Skala Likert}

Merupakan alat berupa skala untuk mengukur persepsi seseorang atau suatu tim mengenai respon dan penilaian mengenai gejala sosial . Tabel 2.2 menunjukkan skor dalam skala Likert. [8].

\begin{tabular}{cccc}
\multicolumn{4}{c}{ Tabel 2.2 Skala Likert } \\
\hline No & Keterangan & $\begin{array}{c}\text { Skor } \\
\text { Positif }\end{array}$ & $\begin{array}{c}\text { Skor } \\
\text { Negatif }\end{array}$ \\
\hline 1 & Sangat Setuju & 5 & 1 \\
2 & Setuju & 4 & 2 \\
3 & Ragu-ragu & 3 & 3 \\
4 & Tidak Setuju & 2 & 4 \\
5 & Sangat Tidak & 1 & 5 \\
& Setuju & & \\
\hline
\end{tabular}

\section{METODOLOGI PENELITIAN}

\subsection{Desain Penelitian}

Penelitian ini dilakukan dengan mengevaluasi usability sistem e-learning pada pembelajaran daring di Politeknik Negeri Jakarta dengan menggunakan desain klausal.

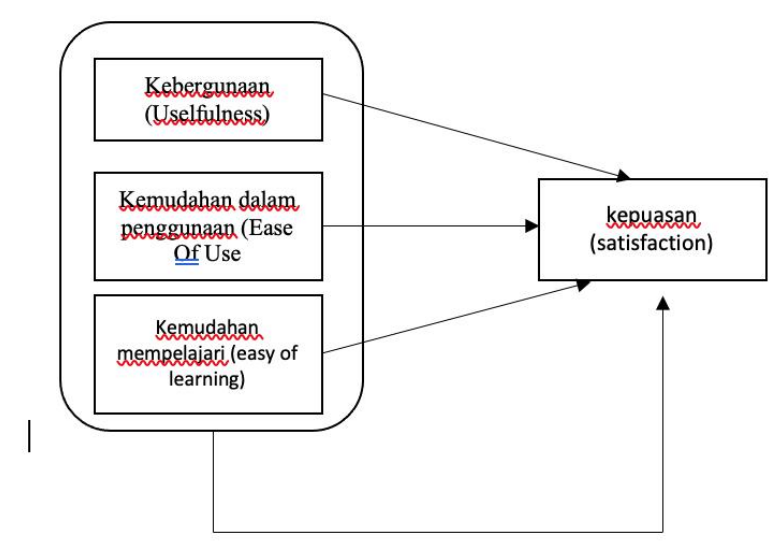

Gambar 3.2 Rancangan atau desain Penelitian

\subsection{Populasi dan Sampel Penelitian}

Populasi didefenisikan sebagai kelompok orang yang menjadi fokus penelitian, sedangkan sampel merupakan bagian dari populasi yang dipilih untuk mewakili seluruh populasi pengguna. [9].

Mengacu pada Nielsen[10] jumlah responden yang dibutuhkan untuk mengukur usabilitas menggunakan kuesioner $\geq 30$. Jumlah responden yang dilibatkan pada penelitian ini adalah sebanyak 150 responden Kriteria responden sebagai berikut : mahasiswa aktif yang berkuliah di 5 Program Studi Politeknik Negeri Jakarta antara lain : Teknik Grafika, Teknik Industri Cetak Kemasan, Teknik Mesin, Kontruksi Gedung dan Konversi Energi. Responden merupakan pengguna aktif yang sudah pernah mengakses e-learning selama minimal 1 bulan.

\subsection{Metode Pengumpulan Data}

Pengumpulan data Primer dalam penelitian ini ialah dengan menggunakan metode kuesioner USE. Dalam mengukur bagaimana suatu objek dapat diandalkan atau dipercaya Cronbach alpha dapat digunakan sebagai media penilaian. Semakin mendekati angka 1 pada hasil penilaian koefesien alpha, pertanyaan dianggap semakin reliable.

\subsection{Instrumen Penelitian}

Kuesioner USE merupakan iInstrumen penelitian yang digunakan dalam penelitian ini. Ada 4 variabel yang digunakan pada kuesioner USE yaitu variabel kebergunaan (uselfulness), kemudahan penggunaan (ease of use), kemudahan mempelajari (ease of learning) serta kepuasaan pengguna (satisfaction) yang mengukur variabel kebergunaan (uselfulness).

Tabel 3.1 Kuesioner USE

\begin{tabular}{|c|c|c|c|c|c|c|}
\hline No & Pernyataan & \multicolumn{5}{|c|}{ Skala Penilaian } \\
\hline & $\begin{array}{l}\text { Variabel Kebergunaan } \\
\text { (Uselfulness) }\end{array}$ & 1 & 2 & 3 & 4 & 5 \\
\hline 1 & $\begin{array}{l}\text { Setelah mengakses } \\
\text { E-learning saya menjadi } \\
\text { lebih mudah memahami } \\
\text { dan mengerti segala } \\
\text { informasi perkuliahan yang } \\
\text { diberikan oleh dosen }\end{array}$ & & & & & \\
\hline 2. & $\begin{array}{l}\text { E-learning membantu saya } \\
\text { menjadi lebih produktif } \\
\text { karena mudah dalam } \\
\text { mengakses, mengunduh } \\
\text { dan mengupload tugas }\end{array}$ & & & & & \\
\hline 3 & $\begin{array}{l}\text { E-learning PNJ berguna } \\
\text { (untuk memberikan } \\
\text { Informasi) }\end{array}$ & & & & & \\
\hline 4. & $\begin{array}{l}\text { E-learning ini dapat } \\
\text { membantu saya memahami } \\
\text { materi yang diberikan } \\
\text { dosen melalui perkuliahan } \\
\text { tatap muka menggunakan } \\
\text { bigbluebutton }\end{array}$ & & & & & \\
\hline
\end{tabular}




\begin{tabular}{|c|c|c|c|c|c|c|}
\hline No & Pernyataan & \multicolumn{5}{|c|}{ Skala Penilaian } \\
\hline 5 & $\begin{array}{l}\text { E-learning ini dapat } \\
\text { membantu saya dalam } \\
\text { mencapai kompetensi } \\
\text { pembelajaran perkuliahan } \\
\text { teori }\end{array}$ & & & & & \\
\hline 6 & $\begin{array}{l}\text { E-learning ini dapat } \\
\text { membantu saya mencapai } \\
\text { kompetensi perkuliahan } \\
\text { praktek }\end{array}$ & & & & & \\
\hline 7 & $\begin{array}{l}\text { E-learning tidak } \\
\text { menghabiskan waktu saya } \\
\text { ketika login, mengisi } \\
\text { attendance, unduh dan } \\
\text { submit tugas }\end{array}$ & & & & & \\
\hline 8 & $\begin{array}{l}\text { Proses perkuliahan jarak } \\
\text { jauh menggunakan } \\
\text { E-learning sama seperti } \\
\text { dengan perkuliahaan tatap } \\
\text { muka }\end{array}$ & & & & & \\
\hline 9 & $\begin{array}{l}\text { Mudah dalam mengakses } \\
\text { E-learning }\end{array}$ & & & & & \\
\hline & $\begin{array}{l}\text { Variabel kemudahan } \\
\text { meggunakan (Ease Of } \\
\text { Use) }\end{array}$ & 1 & 2 & 3 & 4 & 5 \\
\hline 10 & $\begin{array}{l}\text { Tampilan pada e-learning } \\
\text { sederhana sehingga tidak } \\
\text { membingungkan dalam } \\
\text { penggunaannya }\end{array}$ & & & & & \\
\hline 11 & $\begin{array}{l}\text { Saya mudah dalam } \\
\text { mengakses bigbluebutton } \\
\text { untuk mengikuti } \\
\text { perkuliahan tatap muka di } \\
\text { e-learning PNJ }\end{array}$ & & & & & \\
\hline 12 & $\begin{array}{l}\text { Saya sebagai mahasiswa } \\
\text { mudah dalam melakukan } \\
\text { sharing materi presentasi } \\
\text { melalui bigbluebutton } \\
\text { e-learning PNJ }\end{array}$ & & & & & \\
\hline 13 & $\begin{array}{l}\text { Tampilan pada } \\
\text { bigblubutton e-learning } \\
\text { PNJ jelas dan bersih } \\
\text { sehingga proses } \\
\text { perkuliahan tatap muka } \\
\text { dapat berjalan efektif }\end{array}$ & & & & & \\
\hline 14 & $\begin{array}{l}\text { Nyaman melakukan } \\
\text { kegiatan belaar mengajar } \\
\text { menggunakan e-learning }\end{array}$ & & & & & \\
\hline 15 & $\begin{array}{l}\text { Sistem jaringan paa } \\
\text { e-learning sering tidak } \\
\text { stabil }\end{array}$ & & & & & \\
\hline 16 & $\begin{array}{l}\text { Ada fitur undo serta icon } \\
\text { hapus pada e-learning } \\
\text { sehingga saya mudah } \\
\text { memperbaiki jika ada } \\
\text { kesalahan dalam } \\
\text { mengakses/mengupload }\end{array}$ & & & & & \\
\hline
\end{tabular}

\begin{tabular}{|c|c|c|c|c|c|c|}
\hline No & Pernyataan & \multicolumn{5}{|c|}{ Skala Penilaian } \\
\hline 17 & $\begin{array}{l}\text { Ada fitur help (bantuan) } \\
\text { sehingga saya tidak pernah } \\
\text { mengalami kegagalan atau } \\
\text { kesalahan dalam mengikuti } \\
\text { perkuliahan menggunakan } \\
\text { e-learning }\end{array}$ & & & & & \\
\hline 18 & $\begin{array}{l}\text { Tidak ada fitur breakout } \\
\text { pada bigblubutton } \\
\text { sehingga saya kesulitan } \\
\text { dalam melakukan diskusi } \\
\text { kelompok melalui } \\
\text { e-learning }\end{array}$ & & & & & \\
\hline \multirow[t]{2}{*}{19} & $\begin{array}{l}\text { Saya mudah memahami } \\
\text { materi perkuliahan melalui } \\
\text { media e-learning karena } \\
\text { interaksi melalui } \\
\text { forum/live chat pada } \\
\text { e-learning. }\end{array}$ & & & & & \\
\hline & $\begin{array}{l}\text { Variabel Ease Of } \\
\text { learning (kemudahan } \\
\text { mempelajari) }\end{array}$ & 1 & 2 & 3 & 4 & 5 \\
\hline 20 & $\begin{array}{l}\text { Sistem pada e-learning ini } \\
\text { sangat mudah untuk } \\
\text { dipelajari }\end{array}$ & & & & & \\
\hline 21 & $\begin{array}{l}\text { Saya memahami materi } \\
\text { perkuliahan teori melalui } \\
\text { bigblubutton }\end{array}$ & & & & & \\
\hline \multirow[t]{2}{*}{22} & $\begin{array}{l}\text { Saya memahami materi } \\
\text { perkuliahan praktek } \\
\text { melalui bigbluebutton }\end{array}$ & & & & & \\
\hline & $\begin{array}{l}\text { Variabel Satisfaction } \\
\text { Kepuasan. }\end{array}$ & 1 & 2 & 3 & 4 & 5 \\
\hline 23 & $\begin{array}{l}\text { Saya puas mengikuti } \\
\text { perkuliahan jarak jauh } \\
\text { menggunakan e-learning }\end{array}$ & & & & & \\
\hline 24 & $\begin{array}{l}\text { Estetika dan desain yang } \\
\text { minimalis pada E-learning } \\
\text { membuatsemangat belajar }\end{array}$ & & & & & \\
\hline 25 & $\begin{array}{l}\text { Tampilan pada e-learning } \\
\text { PNJ userfriendly }\end{array}$ & & & & & \\
\hline 26 & $\begin{array}{l}\text { Saya puas menggunakan } \\
\text { bigbluebutton pada } \\
\text { E-learning dalam } \\
\text { perkuliahan }\end{array}$ & & & & & \\
\hline
\end{tabular}

\subsection{Prosedur Penelitian}

Langkah-langkah pada penelitian ini:

1. Menjelaskan tujuan tes dan alur penelitian

2. Meminta responden untuk mengisi data diri

3. Meminta responden mengisi kuesioner sesuai petunjuk yang tersedia di kuesioner.

4. Mengumpulkan data hasil kuesioner

5. Melalukan analisis terhadap data yang sudah dikumpulkan

Menarik Kesimpulan sebagai bahan rekomendasi kepada pihak pusat data dan infomasi (Pusdatin) PNJ. 


\section{HASIL DAN PEMBAHASAN}

\subsection{Uji Validitas dan Reliabilitas}

Hasil Uji validitas dan Reliabilitas kuesioner Penelitian dapat dilihat pada tabel berikut ini .

Tabel 4.1 Uji Validitas untuk Variabel $\mathrm{X}_{1}, \mathrm{X}_{2}, \mathrm{X}_{3}$, dan $\mathrm{Y}$

\begin{tabular}{|c|c|c|c|}
\hline No & Variabel & Indikator & Corrected item \\
\hline \multirow[t]{9}{*}{1} & Uselfulness $\left(\mathrm{X}_{1)}\right.$ & $\mathrm{U}_{1}$ & 0,767 \\
\hline & & $\mathrm{U} 2$ & 0,475 \\
\hline & & U3 & 0,522 \\
\hline & & $\mathrm{U} 4$ & 0,751 \\
\hline & & U5 & 0,731 \\
\hline & & $\mathrm{U} 6$ & 0,767 \\
\hline & & $\mathrm{U} 7$ & 0,495 \\
\hline & & $\mathrm{U} 8$ & 0.357 \\
\hline & & U9 & 0,742 \\
\hline \multirow[t]{10}{*}{2} & Ease of Use $\left(\mathrm{X}_{2}\right)$ & EOU10 & 0,450 \\
\hline & & EOU11 & 0,698 \\
\hline & & EOU12 & 0,744 \\
\hline & & EOU13 & 0,750 \\
\hline & & EOU14 & 0,753 \\
\hline & & EOU15 & 0,146 \\
\hline & & EOU16 & 0,188 \\
\hline & & EOU17 & 0,315 \\
\hline & & EOU18 & 0,547 \\
\hline & & EOU19 & 0,373 \\
\hline \multirow[t]{3}{*}{3} & Easy Of Learning (X3) & EOL20 & 0,770 \\
\hline & & EOL21 & 0,729 \\
\hline & & EOL22 & 0,768 \\
\hline \multirow[t]{4}{*}{4} & Satisfaction $(\mathrm{Y})$ & S23 & 0,675 \\
\hline & & S24 & 0,531 \\
\hline & & S25 & 0,758 \\
\hline & & S26 & 0,758 \\
\hline
\end{tabular}

Nilai $r$ tabel dapat diketahui dari tabel statistik, tergantung jumlah responden. Pada penelitian ini jumlah responden adalah sebanyak 150 responden, dengan interval kepercayaan 5\%. Tingkat korelasi dinyatakan valid jika $r$ hitung $>r$ tabel yakni diatas 0,1339. Pada tabel 3.1 dapat disimpulkan bahwa semua variabel memiliki nilai $r>0,1339$ atau lebih besar dari $r$ tabel sehingga dapat dinyatakan semua pernyataan dalam kuesioner adalah valid dan dapat digunakan dalam penelitian.

Tabel 4.2 Hasil Uji Reliabilitas

\begin{tabular}{llll}
\hline Nama Variabel & $\begin{array}{l}\text { Croanbach } \\
\text { Alpa }\end{array}$ & Nilai & Keterangan \\
& 0,936 & 0,6000 & Reliable \\
\hline Uselfulness (X1) & 0,934 & 0,6000 & Reliable \\
\hline Ease of Use (X2) & 0,6000 & Reliable \\
\hline Ease of Learning (X3) & 0,632 & & \\
\hline Satisfaction (Y) & 0,930 & 0,6000 & Reliable \\
\hline
\end{tabular}

Pada tabel 4.2 menunjukkan hasil uji reliabilitas, indikasi reliabilitas dapat dilihat dari nilai Cronbach alpha yang menunjukkan nilai alpha $>0,6$ sehingga dapat dikatakan semua variable memenuhi penilaian reliabilitas.

\subsection{Uji Usabilitas}

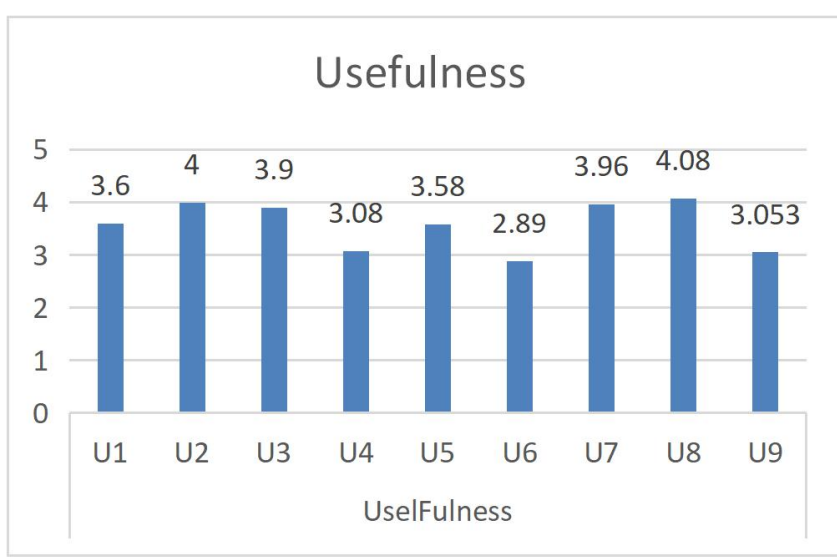

Gambar 1. Uselfulness

Pada gambar 1. Variabel uselfulness (kebergunaan) diatas dapat diketahui bahwasanya rata-rata respon tertinggi dari responden yaitu pada poin pertanyaan ke 2 (U2) dan ke 3 (U3) sebesar 4 dan3,9 dari skala 5. yaitu responden menyatakan e-learning $\mathrm{PNJ}$ membantu menjadi lebih produktif karena mudah dalam mengakses, mengunduh, mengupload tugas serta E-learning ini berguna untuk memberikan informasi seputar perkuliahan. Adapun respon terendah dari responden yaitu pada poin pertanyaan ke 6 (U6) dan ke 9 (U9) sebesar 2,89 dan 3,053 dari skala 5 , yaitu responden menyatakan kurang setuju terhadap pernyataan e-learning ini dapat membantu mencapai kompetensi pembelajaran perkuliahan praktek.,Proses perkuliahan jarak jauh menggunakan E- learning sama seperti dengan perkuliahan tatap muka.

\section{Easy Of USE}

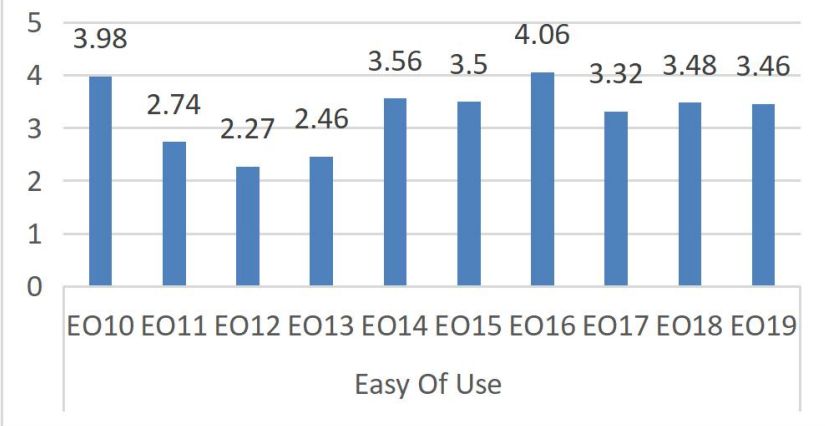

Gambar 2. Easy Of USE 
Pada gambar 2. Variabel Easy of Use mudah digunakan diatas juga dapat diketahui bahwasanya respon terendah dari responden yaitu pada poin pertanyaan ke 12 (EO12) dan ke 11 (EO11) yaitu sebesar sebesar 2,27 dan 2,74 dari skala 5. Yaitu responden menyatakan kurang setuju terhadap pernyataan kemudahan dalam mengakses bigbluebutton dan kurang setuju terhadap pernyataan kemudahan dalam berbagi materi presentasi melalui bigbluebutton.

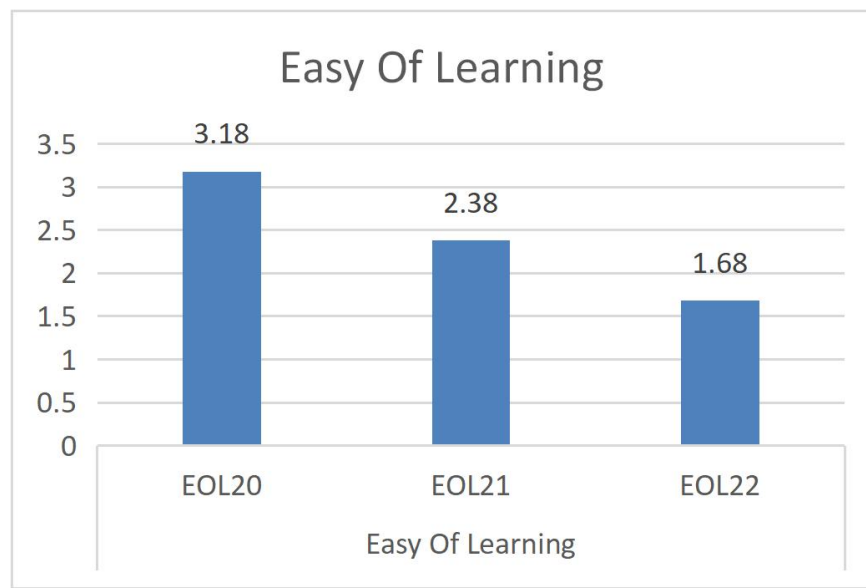

Gambar 3. Easy Of Learning

Pada gambar 3. Variabel Easy of Learning (mudah mempelajari) diatas juga dapat diketahui bahwasanya respon terendah dari responden yaitu pada poin pertanyaan ke 21 (Eol 20 ) dan ke 22 (Eol 22) yaitu sebesar 1,68 dan 2,38 dari skala 5, yaitu responden menyatakan kurang setuju terhadap pernyataan memahami materi perkuliahan teori melalui bigbluebutton, dan sangat kurang setuju terhadap pernyataan memahami materi perkuliahan praktek melalui bigbluebutton.

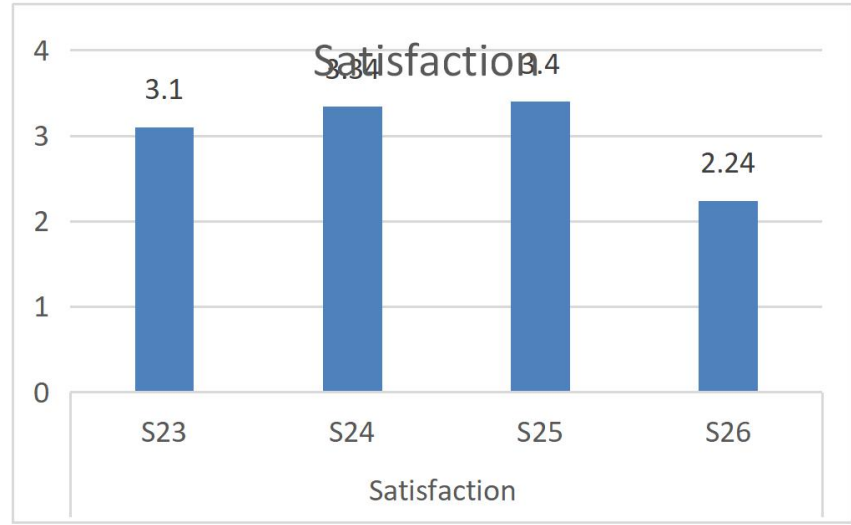

Gambar 4. Variabel Kepuasan

Pada gambar 4. Variabel Kepuasan diatas juga dapat diketahui bahwasanya respon terendah dari responden yaitu pada poin pertanyaan ke 26 (S26) yaitu sebesar Copyright (C) 2020 FT-UHAMKA. - All rights reserved DOI:10.22236/teknoka.v5i.351 sebesar 2,24 dari skala 5, yaitu responden menyatakan kurang setuju terhadap permyataan saya puas menggunakan bigbluebutton pada E-learning dalam perkuliahan tatap muka,

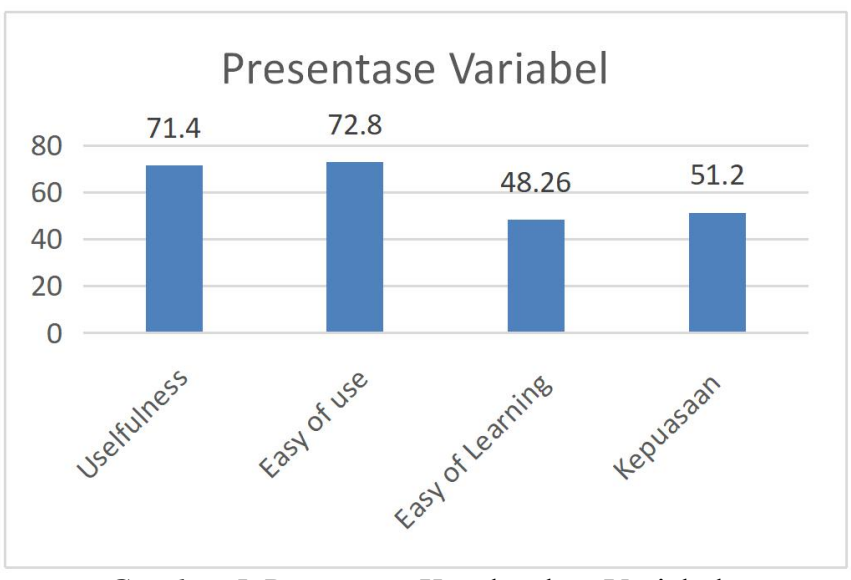

Gambar 5. Presentase Keseluruhan Variabel.

Dari gambar 5. Presentase keseluruhan variabel dapat diketahui bahwasanya untuk variabel uselfulness (kebergunaan) pada E-learning sebesar 71,4 \%, variabel easy of use (mudah di gunakan) sebesar $72,8 \%$, variabel Easy of learning (Kemudahan mempelajari) sebesar 48,25\%, dan satisfaction (Kepuasan) sebesar 51,2\%.

$$
\begin{aligned}
& =\frac{\text { Uselfulness }+ \text { Easy of use }+ \text { Easy of learning }+ \text { Satisfaction }))}{4} X 100 \% \\
& =60,9 \%
\end{aligned}
$$

Pada Perhitungan di atas dapat disimpulkan bahwa usability e-learning Politeknik Negeri Jakarta sebagai media pembelajaran jarak jauh sebesar $60,9 \%$ atau 0,609 termasuk ke dalam usability kategori level baik.

\section{SIMPULAN}

Pada penelitian ini, diketahui bahwasanya saat ini tingkat usability pada e-learning Politeknik Negeri Jakarta sebesar $60,9 \%$ atau 0,609. Angka tersebut termasuk kedalam kategori usabilitas baik. Namun, berdasarkan tabel 2.1 nilai tersebut masih berada dalam kriteria nilai minimun untuk kategori baik. Nilai usability paling rendah yaitu pada variabel easy of learning yang berarti kemudahan dalam mempelajari matakuliah teori maupun praktek yang berkaitan dengan penggunaan. Bigbluebutton yaitu sebesar 48,26\%. Secara umum, fitur yang perlu di perbaiki antara lain : bigbluebutton, attendance, login, serta tambahan fitur berupa notifikasi untuk tugas dan attendance mahasiswa. 


\section{KEPUSTAKAAN}

[1] WHO.2020. WHO Corona virus Disease (COVID-19) Dashboard. Di akses di http://covid19.who.int/t/table pada tanggal 27 November 2020.

[2] Ihsanudin, 2020. Kerja dari rumah belajar dari rumah, ibadah dari rumah, ibadah dari rumah diakses

di

http://nasional.kompas.com/read/2020/03/16/1

5454571/jokowi-kerja-dari-rumah-belajar-darirumah-ibadah-di-rumah-perlu-digencarkan pada tanggal 20 November 2020

[3] Palupi, 2020. Penggunaan Uselearn sebagai metode Evaluasi Usability untuk E-learning. Jurnal Teknik Industri UMM, Vol 15 No 2 tahun 2014.

[4] Ali, 2016. Evaluasi Heuristik Pada Web Based Learning Untuk Meningkatkan Aspek Usability System. Jurnal Insand Comtech, vol 1, No 1, Mei 2016.
[5] Oztekin, A., Kong, Z.J., and Uysal. 2010. Uselearn : A Novel Checklist and Usability Method for learning System by critical metric Analysis. International Journal of Industrial Ergonomics, 40, 455-469

[6] Chiew, T.K \& Salim, S.S. 2003. Webuse : Website Usability Evaluation Tools. Malaysian Journal of Computer Science 6(1), pp.45-57

[7] Marthasari, G. I., \& Hayatin, N. (2017). Analisis Usability Terhadap Sistem Lective Gegulang Berbasis Use Questionnaire.

[8] Sugiono. 2010. Metode Penelitian Kualitatif dan RND. ALFABETA

[9] Umar, Husein., Metode Penelitian Bisnis ed., 2000. Gramedia. Jakarta

[10] Nielsen, J., 2013. Usability Engineering, Boston : Academic Press Professional 